\title{
PENGARUH LATIHAN JUMP TO BOX, DEPTH JUMP DAN SINGLE LEG DEPTH JUMP TERHADAP PENINGKATAN KEKUATAN OTOT TUNGKAI DAN POWER OTOT TUNGKAI
}

\author{
Devi Lestya Pembayun ${ }^{1}$, Oce Wiriawan ${ }^{2}$, dan Hari Setijono ${ }^{3}$ \\ ${ }^{123}$ Pascasarjana Universitas Negeri Surabaya \\ E-mail: devipembayun16070805031@mhs.unesa.ac.id', \\ ocewiriawan@unesa.ac.id ${ }^{2}$, harisetijono@unesa.ac.id ${ }^{3}$
}

Diterima: 10 April 2018; Lolos: 24 Mei 2018; Dipublikasikan: 26 Mei 2018

DOI: https://doi.org/10.29407/js_unpgri.v4i1.12006

\begin{abstract}
Abstrak
Latihan plyometric merupakan bentuk latihan yang cukup beraneka ragam. Dalam penelitian ini peneliti hanya menggunkan tiga bentuk latihan yaitu jump to box, depth jump dan single-leg depth jump. Penelitian ini bertujuan untuk menganalisis pengaruh latihan jump to box, depth jump dan single-leg depth jump terhadap peningkatan kekuatan otot tungkai dan power otot tungkai. Subyek penelitian ini adalah siswa SMA Negeri 1 Ngunut yang mengikuti ektrakurikuler degan jumlah subjek 40 siswa berjenis kelamin laki-laki. Jenis penelitian yang digunakan adalah kuantitatif dengan metode eksperimen semu. Rencana penelitian ini menggunakan matching-only design dan dianalisis menggunakan Anova. Proses pengambilan data kekuatan otot tungkai menggunakan leg dynamo meter dan power otot tungkai menggunakan jump MD pada saat pre test dan post test. Selanjutnya data dianalisis menggunakan SPSS versi 21 . Hasil penelitian ini menunjukkan adanya pengaruh latihan jump to box, depth jump dan single-leg depth jump terhadap peningkatan kekuatan otot tungkai dan power otot tungkai. Sehingga dapat disimpulkan bahwa latihan jump to box, depth jump dan single-leg depth jump sangat efisien untuk meningkatkan kekuatan otot tungkai dan power tungkai.
\end{abstract}

Kata kunci: Plyometric, latihan, kekuatan, box jump, single leg depth jump, power.

\section{THE INFLUENCE OF JUMP TO BOX, DEPTH JUMP DAN SINGLE LEG DEPTH JUMP EXERCISE THROUGH ENHANCING OF LIMBS MUSCLE STRENGTH AND LIMB MUSCLES POWER}

\begin{abstract}
Plyometric exercise is form of exercise which vary. In this research, the researcher only uses three kinds of exercise - jump to box, depth jump and single-leg depth jump. This research aims to analyze the influence of jump to box, depth jump and single-leg depth jump towards enhancement of limbs muscle strength and power. Subject of this research is 40 students of SMA Negeri 1 Ngunut who join extracuricular, all of them are boy. This is quantitative semi experimental research which use matching-only design to clasify the group and Anova to analyze the data. During pretest and posttest, leg dynamometer were used to take the data of limbs muscle strength, while Jump MD were used
\end{abstract}

Email : devipembayun16070805031@mhs.unesa.ac.id

No Handphone : 082338122408

C) 2018 UN PGRI Kediri

p-ISSN: $2548-7833$

e-ISSN: $2477-3379$ 
Devi Lestya Pembayun, Oce Wiriawan, dan Hari Setijono

Pengaruh Latihan Jump To Box, Depth Jump dan Single Leg Depth Jump Terhadap Peningkatan Kekuatan Otot Tungkai dan Power Otot Tungkai

to take the data of of limbs muscle power. Furthermore, the data were analyze using SPSS version 21. The result of this research shooed that there is influence of jump to box, depth jump and single-leg depth jump towards enhancement of limbs muscle strength and power. It can be concluded that plyometric exercise using box jump is very efficient to enhance the leg muscle performance.

Keywords: Plyometric, exercise, strength, box jump, single leg depth jump, power.

\section{PENDAHULUAN}

Pembinaan minat bakat seorang atlet dalam bidang olahraga bukan bersifat rekreatif semata tetapi juga diarahkan untuk mencapai puncak tertinggi yang disebut prestasi. Pembinaan olahraga harus dilakukan secara berjenjang dan terus menerus. Untuk mencapai prestasi ada beberapa aspek yang perlu dilatih, yaitu; latihan fisik, latihan teknik, dan latihan mental

Menurut Sukadiyanto \& Muluk (2011) latihan atau training adalah penerapan dari sebuah perencanaan untuk meningkatkan kemampuan dalam berolahraga yang berisikan materi teori dan praktik, metode dan aturan pelaksanaan sesuai dengan tujuan dan target yang akan dicapai. Ambarukmi (2007) menyatakan bahwa,"Latihan merupakan proses penyempurnaan berolahraga melalui pendekatan ilmiah, khusunya prinsip-prinsip pendidikan, secara teratur dan terencana sehingga mempertinggi kemampuan dan keseimbangan olahraga".

Alasan peniliti memilih bentuk latihan jump to box, depth jump dan single-leg depth jump didasarkan latihan tersebut merupakan betuk latihan yang jarang di lakukan oleh para pelatih atau guru dalam melakukan variasi latihan kekuatan otot tungkai dan power otot tungkai menggunakan media box jump. Selain itu tiga bentuk laitihan ini merupakan bentuk latihan yang mendominasi pembentukan kekuatan otot tungkai dan power tungkai.

Plyometric is a form of exercise used by athletes in all types of sports to improve agility and speed. Plyometric adalah bentuk latihan yang digunakan oleh atlet di semua jenis olahraga untuk meningkatkan kelincahan dan kecepatan. Latihan plyometric adalah bentuk latihan yang dapat digunakan untuk meningkatkan kebugaran biomotorik atlet, 
Devi Lestya Pembayun, Oce Wiriawan, dan Hari Setijono

Pengaruh Latihan Jump To Box, Depth Jump dan Single Leg Depth Jump Terhadap Peningkatan Kekuatan Otot Tungkai dan Power Otot Tungkai

termasuk kekuatan dan kecepatan yang memiliki aplikasi yang sangat luas dalam kegiatan olahraga (Arafat, Mintarto, \& Kusnanik, 2018). Seiring dengan kemajuan zaman yang hampir semua cabang olahraga menggunakan latihan plyometric terutama untuk meningkatkan kekuatan, kecepatan dan power. Daya ledak otot atau power adalah kemampuan otot atau sekelompok otot melakukan kontraksi secara eksplosife dalam waktu yang singkat (Ambarwati, Widiastuti, \& Pradityana, 2017).

Sukadiyanto (2011) menyatakan bahwa kekuatan harus ditingkatkan sebagai landasan yang mendasari dalam komponen biomotor lainnya. Tujuan dari latihan ini menggabungkan gerakan kekuatan otot tungkai dan power otot tungkai untuk menghasilkan gerakan-gerakan explosive. Untuk mendapat lompatan yang tinggi atlet harus memiliki power yang besar yaitu pada otot tungkai. Latihan plyometric merupakan bentuk latihan yang cukup banyak dan beraneka ragam, akan tetapi peneliti hanya memilih jump to box, depth jump dan single-leg depth jump.

Banyak penelitian yang menggunakan bentuk latihan box jump contohnya yang sudah dilakukan oleh Muhammad (2015),"Pengaruh Latihan Plyometrc Depth Jump dan Multiple Box-To-Box Squoat Jump Terhadap Peningkatan kecepatan Gerak dan Explosive Power Otot Tungkai". Yang membedakan dari penelitian saat ini adalah tujuan otot yang dilatih berbeda dan bentuk latihan yang berbeda meskipun samasama menggunakan box jump. Melihat kurangnya variasi latihan yang diberikan guru dalam melatih sisiwa untuk meningkatkan kekuatan otot tungkai dan power tungkai yang menjadi alasan peneliti ingin memberikan inovasi baru yaitu dengan variasi latihan dari box jump.

\section{METODE}

Dalam penelitian ini penulis mengunakan metode eksperimen semu atau (Quasi Eksperimen) dengan desain Matching-only design. Penelitian ini tidak menggunakan random sebagai cara memasukkan subjek ke dalam atau dengan yang lain berdasarkan variabel tertentu (Maksum, 2012). 
Devi Lestya Pembayun, Oce Wiriawan, dan Hari Setijono

Pengaruh Latihan Jump To Box, Depth Jump dan Single Leg Depth Jump Terhadap Peningkatan Kekuatan Otot Tungkai dan Power Otot Tungkai

Dalam memntukan besaran sampel sebuah riset tidak ada ketentuan absolut, yang terpenting artinya persentase sampel harus bersumber dari populasi yang sudah ditentukan oleh peneliti (Maksum, 2012). Untuk menentukan sampel yang dapat merepresentasikan dari jumlah populasi harus menggunakan rumus Sovlin.

Dalam rumus ini taraf kesalahan yang digunakan adalah $5 \%$ atau 0,05 yang merupakan sebuah besaran sampel yang telah digunakan, berikut ini adalah uraiannya:

$$
\begin{array}{lll}
\text { Rumus Slovin, yaitu : } & \mathrm{n} & =n=\frac{N}{1+N e^{2}} \\
\text { Dimana } & \mathrm{N} & =\text { Jumlah Populasi } \\
& \mathrm{e} & =\text { Taraf Kesalahan }
\end{array}
$$

Kali ini peneliti menggunakan jumlah populasi 44 siswa putra yang mengikuti ektra kurikuler bola voli berjumlah 14 siswa, karate 20 siswa dan bola basket 10 siswa. Setelah mengetahui jumlah populasi dalam penelitian ini, maka selanjutnya akan dilakukan rumus penentuan sampel Solvin.

$$
\begin{gathered}
n=\frac{N}{1+N e^{2}} \\
=\frac{44}{1+44(0,05)^{2}} \\
=\frac{44}{1+44(0,0025)} \\
=\frac{44}{1+0,11} \\
=39,96
\end{gathered}
$$

Dalam pengambilan sampel menggunakan teknik purposive sampling, menurut Mahardika (2010) teknik pengambilan sampel purposive menghendaki pengambilan sampel dengan tujuan tertentu yang disesuaikan dengan keperluan penelitian.

Empat puluh dari empat puluh lima siswa yang mengikuti ektrakurikuler terpilih berdasarkan kriteria yang sudah ditentukan yaitu siswa SMA Negri 1 Ngunut yang mengikuti ektrakurikuler bolavoli, bola basket dan karate, berjenis kelamin laki-laki, tahap berikutnya adalah 
Devi Lestya Pembayun, Oce Wiriawan, dan Hari Setijono

Pengaruh Latihan Jump To Box, Depth Jump dan Single Leg Depth Jump Terhadap Peningkatan Kekuatan Otot Tungkai dan Power Otot Tungkai

tahap pretest dimana dari ke empat puluh siswa yang tepilih akan di tes kekuatan otot tungkai dan power tungkai menggunakan leg dynamo meter dan jump MD tes ini dilakukan untuk mengetahui data awal sebelum di lakukannya perlakuan. Dari data tersebut maka didapatkan hasil yang dapat merengking untuk mempermudahkan pembentukan kelompok yang terdiri dari (kelompok satu jump to box, kelompok dua depth jump, kelompok tiga single leg depth jump dan yang terahir kelompok 4 sebagai kelompok kontrol). Dari tiga kelompok box jump ini akan di berikan sebuah perlakuan tiga kali dalam satu minggu selama enam bulan yang terhitung keseluruhan dalam pertemuanya adalah 18 minggu perlakuan.

1) Kelompok Eksperimen I

Selama penelitian berlangsung yang dilakukan kelompok eksperimen I adalah melakukan latihan jump to box dengan 3 kali pertemuan dalam satu minngu. Berikut ini adalah gambaran cara melakukan latihan jump to box menurut (Chu,2013)

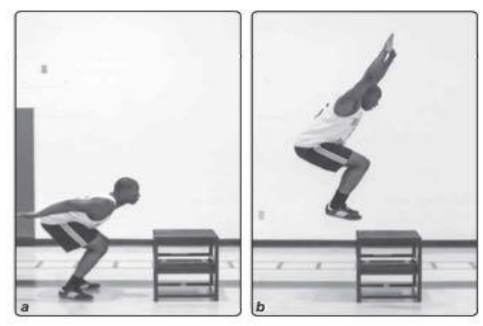

Gambar 1. Jump To Box (Chu, 2013)

2) Kelompok Eksperimen II

Sama halnya dengan kelompok eksperimen I yang di berikan latihan selama 3 kali pertemuan dalam satu minggu yang membedakan dari kelompok eksperimen I adalah latihannya, latihan yang di berikan di kelompok ekperimen II adalah depth jump. Berikut ini adalah cara latihannya menurut (Chu,2012). 


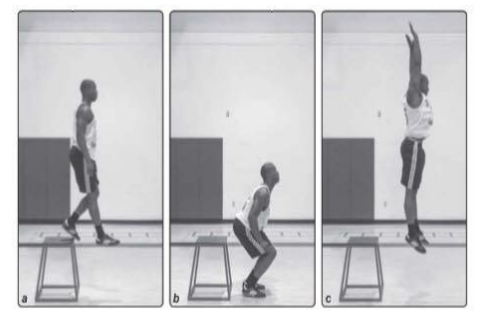

Gambar 2. Depth Jump (Chu,2013)

3) Kelompok Eksperimen III

Yang membedakan dari kelompok eksperimen III hanya bentuk latihan bentuk latihan yang di berikan kelompok III adalah latihan singleleg depth jump dengan 3 kali pertemuan dalam satuminggunya. Berikut ini adalah gambaran latihan single-leg depth jump menurut (Chu,2013).

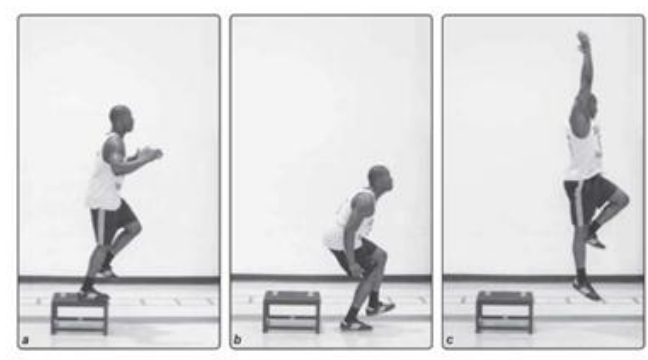

Single-leg Depth Jump

4) Kelompok Kontrol

Kelompok kontrol di bebaskan dari bentuk latihan akan tetapi kelompok tersebut tetap melakukan latihan konvensional.

Menurut Bompa (2011) pengembangan power dioptimalkan dengan beban rendah sampai sedang dan repetisi rendah (30-60\% dari $1 \mathrm{RM}$ ) pada latihan plyometric untuk menentukan volume pada saat latihan yaitu menggunakan penghitungan foot contact (kontak kaki). Nurhasan (2011) mengatakan bahwa frekuensi latihan yang efektif adalah 3-5 kali seminggu, apabila kurang dari 3-5 kali maka tidak akan memberikan dampak bagi tubuh.

Analisis data yang digunakan yaitu: 1) Analisis data deskriptif yang peneliti digunkana untuk mengetahui frekuensi, prosentase dan rata-rata, 2) Untuk analisa data menggunakan program SPSS 21 yang mana program ini membantu untuk menghitung uji normalitas suatu data dari hasil penelitian yang telak dilakukan, uji Kolmogorov-Smirnov bila 
Devi Lestya Pembayun, Oce Wiriawan, dan Hari Setijono

Pengaruh Latihan Jump To Box, Depth Jump dan Single Leg Depth Jump Terhadap Peningkatan Kekuatan Otot Tungkai dan Power Otot Tungkai

perolehan data normal dilanjutkan dengan uji paired sample t-test, kemudian uji homogenitas dan ANOVA untuk mengetahui metode latihan mana yang paling efektif untuk meningkatakan kinerja fisik otot kaki.

\section{HASIL DAN PEMBAHASAN}

\section{Hasil}

\section{1) Deskripsi Data Kelompok Eksperimen I (Latihan Jump to Box)}

Dalam pembahasan subab ini akan dipaparkan hasil analisis dari pretest, posttest, selisih rata-rata, selisih rata-rata dan standar deviasi dari masing-masing variabel terikat (kekuatan otot tungkai dan power otot tungkai) pada kelompok I.

Tabel 1. Perolehan Data Pretest dan Posttest Kelompok Eksperimen I (Latihan Jump To Box).

\begin{tabular}{|c|c|c|c|c|c|}
\hline \multicolumn{6}{|c|}{ Kelompok Eksperimen 1 (Latihan Jump To Box) } \\
\hline \multirow{2}{*}{ No } & \multirow{2}{*}{ Nama } & \multicolumn{2}{|c|}{ Kekuatan } & \multicolumn{2}{|c|}{ Power } \\
\hline & & Pretest & Posttest & Pretest & Posttest \\
\hline 1 & WMFR & 129 & 130 & 582 & 583 \\
\hline 2 & ABDS & 116 & 118 & 496 & 498 \\
\hline 3 & MIDK & 114 & 115 & 478 & 479 \\
\hline 4 & SE & 108 & 110 & 441 & 442 \\
\hline 5 & AR & 120 & 121 & 439 & 441 \\
\hline 6 & BU & 119 & 120,5 & 356 & 358 \\
\hline 7 & SAPC & 110 & 111 & 349 & 350 \\
\hline 8 & MNA & 117 & 119 & 312 & 313 \\
\hline 9 & SFN & 103 & 105 & 305 & 307 \\
\hline \multirow[t]{2}{*}{10} & AGRJ & 142 & 143 & 181 & 182 \\
\hline & rata & 117,80 & 119,25 & 393,90 & 395,30 \\
\hline \multicolumn{2}{|c|}{ Selisih rata-rata } & \multicolumn{2}{|c|}{1,45} & \multicolumn{2}{|c|}{1.40} \\
\hline & $D$ & 11,11 & 10,86 & 115,72 & 115,74 \\
\hline
\end{tabular}

Dari hasil tabel 1 dapat diketahui adanya peningkatan nilai rata-rata antara pretest dan posttest pada variabel dependent (kekuatan otot tungkai dan power otot tungkai). Nilai pretest sebesar 117,80 dan nilai posttest sebesar 119,25. Terjadi peningkatan sebesar 1,45 dari sebelum sampai selesai diberi perlakuan. Hal ini berarti menunjukkan adanya peningkatan nilai rata-rata pretest dan posttest pada kekuatan otot tungkai 
Devi Lestya Pembayun, Oce Wiriawan, dan Hari Setijono

Pengaruh Latihan Jump To Box, Depth Jump dan Single Leg Depth Jump Terhadap Peningkatan Kekuatan Otot Tungkai dan Power Otot Tungkai

Maka dapat disimpulkan pemberian perlakuan jump to box berpengaruh signifikan terhadap hasil kekuatan otot tungkai.

Demikian pula perolehan dari data pada power otot tungkai yang menunjukkan adanya peningkatan power otot tungkai yang signifikan setelah diberikan perlakuan selama enam minggu. Hal ini dapat dilihat dari perolehan data pretest sebesar 393,90 dan perolehan data posttest sebesar 395,30 . Terjadi peningkatan sebesar 1,40 dari sebelum sampai selesai diberi perlakuan. Dari peningkatan data tersebut dapat disimpulkan terdapat pengaruh yang signifikan dalam pemberian perlakuan selama 6 minggu dengan 3 kali pertemuan dalam satu minggu dengan latihan jump to box pada kelompok ekperimen I terhadap power otot tungkai.

\section{2) Deskripsi Data Kelompok Eksperimen II (Latihan depth jump)}

Deskriptif dari kelompok ekperimen II ini menggambarkan hasil analisa dari data pretest, posttest, rata-rata, selisih rata-rata dan standar deviansi dar masing-masing variabel terikat yaitu kekuatan otot tungkai dan (power otot tungkai).

Tabel 2. Perolehan Hasil dari Pretest dan Posttest Kelompok Eksperimen II (Latihan Depth Jump)

\begin{tabular}{|c|c|c|c|c|c|}
\hline \multicolumn{6}{|c|}{ Kelompok Eksperimen 2 (Latihan Depth Jump) } \\
\hline \multirow{2}{*}{ NO } & \multirow{2}{*}{ NAMA } & \multicolumn{2}{|c|}{ Kekuatan } & \multicolumn{2}{|c|}{ Power } \\
\hline & & Pretest & Posttest & Pretest & Posttest \\
\hline 1 & MSS & 120,5 & 122 & 519 & 520 \\
\hline 2 & AEP & 117,5 & 119 & 502 & 504 \\
\hline 3 & WAP & 104,5 & 106 & 476 & 477 \\
\hline 4 & AIM & 122 & 123,5 & 449 & 452 \\
\hline 5 & RDT & 153 & 154 & 430 & 431 \\
\hline 6 & DDP & 105 & 106 & 374 & 375 \\
\hline 7 & MKR & 124 & 125,5 & 349 & 352 \\
\hline 8 & GGP & 115 & 118 & 316 & 318 \\
\hline 9 & $\mathrm{MRH}$ & 102 & 103,5 & 298 & 299 \\
\hline 10 & RKS & 117 & 118,5 & 234 & 236 \\
\hline \multicolumn{2}{|c|}{ Rata-rata } & 118,05 & 119,60 & 394,70 & 396,40 \\
\hline \multicolumn{2}{|c|}{ Selisih rata-rata } & \multicolumn{2}{|c|}{1,55} & \multicolumn{2}{|c|}{1,70} \\
\hline & $\mathrm{D}$ & 14,53 & 14,42 & 95,25 & 95,12 \\
\hline
\end{tabular}


Devi Lestya Pembayun, Oce Wiriawan, dan Hari Setijono

Pengaruh Latihan Jump To Box, Depth Jump dan Single Leg Depth Jump Terhadap Peningkatan Kekuatan Otot Tungkai dan Power Otot Tungkai

Berdasarkan perolehan data rata-rata dari tabel 2 terdapat peningkatan kelompok eksperimen II dari hasil pretest dan posttest pada variabel dependent (kekuatan otot tungkai dan power otot tungkai). Yang dibuktikan dari nilai rata-rata pada saat posttest $(119,6)$ lebih baik dibandingkan nilai pada saat pretest $(118,05)$, dengan selisih rata-rata 1,55. Deangan demikian kelompok eksperimen II dengan adanya pemberian perlakuan selama enam minggu dengan bentuk latihan depth jump terdapat peningkatan kekuatan otot tungkai.

Nilai dari power pada tabel rata-rata posttest sebesar 396,4 menjelaskan lebih baik dibanding dengan nilai rata-rata pretest sebesar 394,7, selisih dari keduanya sebesar 1,7. Gambaran ini cukup menjelaskan terdapat adanya peningkatan dalam latihan dari depth jump terhadap peningkatan kekuatan power otot tungkai.

Dari peningkatan data diatas dapat disimpulkan terdapat pengaruh yang signifikan dalam pemberian perlakuan selama 6 minggu dengan 3 kali pertemuan dalam satu minggu dengan latihan depth jump pada kelompok ekperimen II terhadap kekuatan otot tungkai dan power otot tungkai.

\section{3) Deskripsi Data Kelompok Eksperimen III (Latihan single-leg depth jump)}

Berikut ini merupakan pemaparan dari hasil pretest dan Posttest dari kelompok eksperimen III yang mencoba melihat rata-rata, selisih ratarata dan standar deviasi.

Tabel 3. Perolehan Hasil dari Pretest dan Posttest Kelompok Eksperimen III (Latihan Single-Leg Depth Jump)

\begin{tabular}{cccccc}
\hline \multicolumn{6}{c}{ Kelompok Eksperimen 3 (Single Leg Depth Jump) } \\
\hline & & \multicolumn{3}{c}{ Kekuatan } & \multicolumn{2}{c}{ Power } \\
\cline { 3 - 6 } NO & NAMA & Pretest & Posttest & Pretest & Posttest \\
\hline 1 & ARA & 107 & 109 & 590 & 592 \\
\hline 2 & AN & 159 & 160 & 505 & 507 \\
\hline 3 & MFAH & 115,5 & 116,5 & 468 & 470 \\
\hline 4 & JHY & 120 & 122 & 449 & 452 \\
\hline 5 & FDC & 132 & 133,5 & 427 & 428 \\
\hline 6 & AYP & 121 & 122,5 & 378 & 379 \\
\hline 7 & FT & 122 & 124 & 323 & 326 \\
\hline & & & & SPORTIF, 4 (1) 2018|87-104
\end{tabular}


Devi Lestya Pembayun, Oce Wiriawan, dan Hari Setijono

Pengaruh Latihan Jump To Box, Depth Jump dan Single Leg Depth Jump Terhadap Peningkatan Kekuatan Otot Tungkai dan Power Otot Tungkai

\begin{tabular}{cccccc}
\hline 8 & JA & 108 & 110 & 317 & 319 \\
\hline 9 & $\mathrm{ML}$ & 116,5 & 117,5 & 276 & 277 \\
\hline 10 & $\mathrm{FI}$ & 142 & 144 & 251 & 253 \\
\hline \multicolumn{2}{c}{ Rata-rata } & 124,30 & 125,90 & 398,40 & 400,30 \\
\hline \multicolumn{2}{c}{ Selisih rata-rata } & \multicolumn{3}{c}{1,60} & \multicolumn{2}{c}{1,90} \\
\hline \multicolumn{2}{c}{ SD } & 15,21 & 15,09 & 102,83 & 102,92 \\
\hline
\end{tabular}

Berdasarkan nilai rata-rata pada tabel 3 terdapat peningkatan dari pretest dan posttest dari latihan single-leg depth jump. Nilai rata-rata hasil posttest dari kekuatan otot tungkai sebesar 125,9, hal ini dapat menegaskan bahwa adanya peningkatan, sebelumnya rata-rata pada saat dilakukan pretest hanya mencapai 124,3 selisih rata-rata sebesar 1,6. Dari pernyataan data yang sudah dijelaskan diatas menunjukkan adanya pengaruh yang signifikan dari latihan single-leg depth jump terhadap peningkatan kekuatan otot tungkai.

Nilai peningkatan power dari rata-rata posttest sebesar 400,3 menunjukkan lebih besar dibandingkan nitai dari rata-rata pretest sebesar 398,4, untuk selisih rata-rata dari hasil pretest dan Posttest sebesar 1,9. Melihat perolehan data diatas maka terdapat pengaruh yang signifikan dari pemberian perlakuan single-leg depth jump terhadap variabel dependen yang dilakukan selama 6 minggu dengan 3 kali pertemuan dalam satu minggu.

Dari peningkatan data diatas dapat disimpulkan terdapat pengaruh yang signifikan dalam pemberian perlakuan selama 6 minggu dengan 3 kalipertemuan dalam satu minggu dengan latihan single leg depth jump pada kelompok ekperimen II terhadap kekuatan otot tungkai dan power otot tungkai.

\section{4) Deskripsi Data Kelompok Kontrol}

Tahap pengumpulan data dari kelompok kontrol sama persis yang dilakukan pada kelompok eksperimen I, II, dan III. Sehingga deskripsi dari kelompok kontrol juga sama-sama memberikan gambaran terkait nilai pretest, posttest, rata-rata, selisih rata-rata dan standar deviansi dari masing-masing variabel terikat yaitu kekuatan otot tungkai dan power otot tungkai 
Devi Lestya Pembayun, Oce Wiriawan, dan Hari Setijono

Pengaruh Latihan Jump To Box, Depth Jump dan Single Leg Depth Jump Terhadap Peningkatan Kekuatan Otot Tungkai dan Power Otot Tungkai

Tabel 4. Perolehan Hasil dari Pretest dan Posttest Kelompok Kontrol

\begin{tabular}{cccccc}
\hline \multicolumn{6}{c}{ Kelompok Kontrol } \\
\hline \multirow{2}{*}{ No } & \multirow{2}{*}{ Nama } & \multicolumn{2}{c}{ Kekuatan } & \multicolumn{2}{c}{ Power } \\
\cline { 3 - 6 } & & Pretest & Posttest & Pretest & Posttest \\
\hline 1 & LZA & 124,5 & 124 & 512 & 512 \\
\hline 2 & MIA & 125 & 124 & 509 & 510 \\
\hline 3 & DAY & 132 & 131 & 460 & 459 \\
\hline 4 & BDC & 123 & 123 & 456 & 455 \\
\hline 5 & SIM & 115 & 114 & 410 & 410 \\
\hline 6 & YWS & 101 & 101 & 396 & 395 \\
\hline 7 & ANP & 122,5 & 123 & 320 & 321 \\
\hline 8 & BPBS & 123,5 & 123,5 & 319 & 319 \\
\hline 9 & MAI & 99 & 100 & 268 & 267 \\
\hline 10 & RRA & 133,5 & 134 & 258 & 256 \\
\hline \multicolumn{2}{c}{ Rata-rata } & 119,90 & 119,75 & 390,80 & 390,40 \\
\hline Selisih rata-rata & \multicolumn{3}{c}{$-0,15$} & \multicolumn{3}{c}{$-0,40$} \\
\hline \multicolumn{7}{c}{ SD } & 11,67 & 11,43 & 94,86 & 95,21 \\
\hline \multicolumn{7}{c}{}
\end{tabular}

Dari perolehan hasil rata-rata pada tabel 4 dapat diketahui adanya peningkatan nilai rata-rata anatara pretest dan posttest pada variabel dependent. Nilai dari penurunan kekuatan otot tungkai pada rata-rata posttest sebesar 119,75 hal ini menunjukkan adanya penurunan dari nilai rata-rata pretest sebesar 119,90 selisih rata-rata sebesar $-0,15$. Melihat penurunan diatas maka komponen kekuatan otot tungkai dari kelompok kontrol tidak dinyatakan ada peningkatan yang signifikan.

Sedangkan nilai dari power otot tungkai pada rata-rata posttest sebesar 390,4 menunjukkan adanya penurunan dari nilai rata-rata pada saat pretest sebesar 390,80 selisih rata-rata dari keduanya sebesar -0,4. Melihat penurunan data diatas maka komponen dari power otot tungkai dari kelompok kontrol tidak ada peningkatan yang signifikan.

Dari semua data yang sudah dipaparkan dapat disimpilkan bahwa terdapat peningkatan pretest dan posttest pada variabel dependen (kekuatan otot tungkai dan power otot tungkai) untuk kelompok I, II, dan III. Kelompok kontrol disini berguna sebagai pembanding dari ketiga kelompok eksperimen, maka peningkatan dari ketiga kelompok eksperimen disebabkan oleh adanya perlakuan. 
Devi Lestya Pembayun, Oce Wiriawan, dan Hari Setijono

Pengaruh Latihan Jump To Box, Depth Jump dan Single Leg Depth Jump Terhadap Peningkatan Kekuatan Otot Tungkai dan Power Otot Tungkai

\section{Uji Prasyarat Data}

1. Uji Normalitas Data

Uji normalitas bertujuan untuk mengetahui normal atau tidaknya suatu data yang diperoleh pada saat melakukan tes. Pada uji data ini menggunakan One-Sample Kolmogorov-Smirnov Test. Dalam menentukan kesimpulan maka digunakan kriteria pengujian normalitas data sebagai berikut :

Tabel 5. Hasil Uji Normalitas Data Pretest

\begin{tabular}{|c|c|c|c|c|c|c|}
\hline & \multicolumn{3}{|c|}{ Kolmogorov-Smirnov ${ }^{2}$} & \multicolumn{3}{|c|}{ Shapiro-Wilk } \\
\hline & Statistic & $d f$ & Sig. & Statistic & $d f$ & Sig. \\
\hline $\begin{array}{l}\text { Jump To Box } \\
\text { Pretest } \\
\text { (Kekuatan) }\end{array}$ & 222 & 10 & 179 & 926 & 10 & 408 \\
\hline $\begin{array}{l}\text { Jump To Box } \\
\text { Pretest (Power) }\end{array}$ & 152 & 10 & ,200* & 977 & 10 & 945 \\
\hline $\begin{array}{l}\text { Depth Jump } \\
\text { Pretest } \\
\text { (Kekuatan) }\end{array}$ & 241 & 10 & 103 & ,842 & 10 & ,047 \\
\hline $\begin{array}{l}\text { Depth Jump } \\
\text { Pretest (Power) }\end{array}$ & 145 & 10 & $200^{*}$ & 956 & 10 & 743 \\
\hline $\begin{array}{l}\text { Single Leg Depth } \\
\text { Jump Pretest } \\
\text { (Kekuatan) }\end{array}$ & 257 & 10 & ,060 & 885 & 10 & 151 \\
\hline $\begin{array}{l}\text { Singel Leg Depth } \\
\text { Jump pretest } \\
\text { (Power) }\end{array}$ & 157 & 10 & $200^{*}$ & 966 & 10 & 854 \\
\hline $\begin{array}{l}\text { Kelompok Kontrol } \\
\text { Pretest } \\
\text { (Kekuatan) }\end{array}$ & 288 & 10 & 018 & ,856 & 10 & 069 \\
\hline $\begin{array}{l}\text { Kelompok Kontrol } \\
\text { Pretest (Power) }\end{array}$ & 172 & 10 & $200^{*}$ & 917, & 10 & 332 \\
\hline
\end{tabular}

Berdasarkan uraian tabel 5 maka bahwa seluruh skor pretest dari seluruh kelompok berdistribusi normal karena sig >0,05.

Tabel 6. Uji Normalitas Data Posttest

\begin{tabular}{lcccccc}
\hline \multicolumn{9}{c}{ Tests of Normality } \\
\hline & \multicolumn{3}{c}{ Kolmogorov-Smirnov } & \multicolumn{4}{c}{ Shapiro-Wilk } \\
\cline { 2 - 7 } & Statistic & $d f$ & Sig. & Statistic & $d f$ & Sig. \\
\hline $\begin{array}{l}\text { Jump To Box } \\
\begin{array}{l}\text { Posttest } \\
\text { (Kekuatan) }\end{array}\end{array}$ & 236 & 10 &, 122 &, 920 & 10 &, 358 \\
\hline
\end{tabular}


Devi Lestya Pembayun, Oce Wiriawan, dan Hari Setijono

Pengaruh Latihan Jump To Box, Depth Jump dan Single Leg Depth Jump Terhadap Peningkatan Kekuatan Otot Tungkai dan Power Otot Tungkai

\begin{tabular}{lllllll}
\hline $\begin{array}{l}\text { Jump To Box } \\
\text { Posttest (Power) }\end{array}$ &, 154 & 10 &, $200^{*}$ &, 976 & 10 &, 943 \\
\hline $\begin{array}{l}\text { Depth Jump } \\
\begin{array}{l}\text { Posttest } \\
\text { (Kekuatan) }\end{array}\end{array}$ &, 241 & 10 &, 103 &, 840 & 10 &, 044 \\
\hline $\begin{array}{l}\text { Depth Jump } \\
\text { Posttest (Power) }\end{array}$ &, 142 & 10 &, $200^{*}$ &, 956 & 10 &, 737 \\
\hline $\begin{array}{l}\text { Single Leg Depth } \\
\text { Jump Posttest } \\
\text { (Kekuatan) }\end{array}$ &, 248 & 10 &, 083 &, 886 & 10 &, 153 \\
$\begin{array}{l}\text { Single Leg Depth } \\
\text { Jump Posttest } \\
\text { (Power) }\end{array}$ &, 153 & 10 &, $200^{*}$ &, 967 & 10 &, 857 \\
$\begin{array}{l}\text { Kelompok } \\
\text { Kontrol Posttest } \\
\text { (Kekuatan }\end{array}$ &, 312 & 10 &, 007 &, 853 & 10 &, 063 \\
$\begin{array}{l}\text { Kelompok } \\
\text { Kontrol Posttest } \\
\text { (Power) }\end{array}$ &, 167 & 10 &, $200^{*}$ &, 919 & 10 &, 352 \\
\hline
\end{tabular}

Berdasarkan uraian tabel 6 maka bahwa seluruh skor posttest dari seluruh kelompok berdistribusi normal karena sig >0,05.

2. Uji Homogen

Uji homogenitas bertujuan untuk memastikan bahwa varian dari setiap kelompok sama (homogen) atau tidak sama (heterogen). homogenitas dilakukan untuk memperlihatkan bahwa dua atau lebih kelompok data sampel berasal dari populasi yang memiliki varians yang sama (homogen).

Tabel 7. Uji Homogenitas

\begin{tabular}{lcccc}
\hline \multicolumn{5}{c}{ Test of Homogeneity of Variances } \\
\hline & $\begin{array}{l}\text { Levene } \\
\text { Statistic }\end{array}$ & df1 & df2 & Sig. \\
\hline $\begin{array}{l}\text { Pretest Kekuatan dari } 4 \\
\text { Kelompok }\end{array}$ &, 413 & 3 & 36 &, 744 \\
\hline $\begin{array}{l}\text { Posttest Kekuatan dari } 4 \\
\text { Kelompok }\end{array}$ &, 459 & 3 & 36 &, 713 \\
\hline $\begin{array}{l}\text { Selisih Dari Semua } \\
\text { Kelompok }\end{array}$ & 1,469 & 3 & 36 &, 239 \\
\hline
\end{tabular}

Berdasarkan penjelasan tabel 7 diketahui data seluruh variabel homogen dikarenakan sig >0,05.

3. Uji Beda 
Devi Lestya Pembayun, Oce Wiriawan, dan Hari Setijono

Pengaruh Latihan Jump To Box, Depth Jump dan Single Leg Depth Jump Terhadap Peningkatan Kekuatan Otot Tungkai dan Power Otot Tungkai

Untuk mengetahi adanya pengaruh dari perlakuan pada variabel yang digunakan maka dilakukan paired t test. Berikut penjabaran dari dari uji beda dari masing-masing kelompok

Tabel 8. Hasil Uji beda kelompok Jump To Box

\begin{tabular}{llr}
\hline & Paired samples Test & Sig. (2tailed) \\
\hline \multirow{2}{*}{ Jump To Box } & pre-pos Kekuatan &, 000 \\
\cline { 2 - 3 } & Pre-pos Power &, 000 \\
\hline
\end{tabular}

Hipotesis :

a. $\mathrm{H}_{0}=$ Tidak dapat pengaruh dari perlakuan

b. $\mathrm{H}_{1}=$ Terdapat pengaruh dari perlakuan

Kriteria Pengujian :

a. $\mathrm{H}_{0}$ ditolak $\mathrm{H}_{1}$ diterima jika sig $>0,05$

b. $\mathrm{H}_{0}$ ditolak $\mathrm{H}_{1}$ ditolak jika sig $>0,05$

Dari data tabel 8 signifikan yang didapatkan oleh kekuatan otot tungkai 0,000 dan power otot tungkai 0,000 atau sig < 0,05 maka terdapat pengaruh yang signifikan latihan jump to box terhadap peningkatan kekuatan otot tungkai dan power otot tungkai.

Tabel 9. Hasil Uji Beda Kelompok Depth Jump

\begin{tabular}{lcr}
\hline & Paired samples Test & Sig. (2tailed) \\
\hline \multirow{2}{*}{ Depth Jump } & pre-pos Kekuatan &, 000 \\
\cline { 2 - 3 } & Pre-pos Power & 000 \\
\hline
\end{tabular}

Dari data tabel 9 signifikan yang didapatkan oleh kekuatan otot tungkai 0,000 dan power otot tungkai 0,000 atau sig $<0,05$ maka terdapat pengaruh yang signifikan latihan depth jump terhadap peningkatan kekuatan otot tungkai dan power tungkai.

Tabel 10. Hasil Uji Beda Kelompok Single Leg Depth Jump

\begin{tabular}{llr}
\hline \multicolumn{2}{c}{ Paired samples Test } & Sig. (2tailed) \\
\hline \multirow{2}{*}{ Single Leg Depth Jump } & pre-pos Kekuatan &, 000 \\
\cline { 2 - 3 } & Pre-pos Power &, 000 \\
\hline
\end{tabular}

Dari data tabel 10 signifikan yang didapatkan oleh kekuatan otot tungkai 0,000 dan power otot tungkai 0,000 atau sig $<0,05$ maka terdapat 
Devi Lestya Pembayun, Oce Wiriawan, dan Hari Setijono

Pengaruh Latihan Jump To Box, Depth Jump dan Single Leg Depth Jump Terhadap Peningkatan Kekuatan Otot Tungkai dan Power Otot Tungkai

pengaruh yang signifikan latihan single-leg depth jump terhadap peningkatan kekuatan otot tungkai dan power tungkai.

Tabel 11. Hasil Uji Beda Kelompok Kontrol

\begin{tabular}{rrr}
\hline \multicolumn{2}{c}{ Paired samples Test } & \multicolumn{1}{c}{ Sig. (2 tailed) } \\
\hline \multirow{2}{*}{ Kelompok Kontrol } & pre-pos Kekuatan &, 520 \\
\cline { 2 - 3 } & Pre-pos Power &, 223 \\
\hline
\end{tabular}

Dari data tabel 11 signifikan yang didapatkan oleh kekuatan otot tungkai 0,520 dan power otot tungkai 0,223 atau sig < 0,05 maka tidak terdapat pengaruh yang signifikan dari kelompok kontrol terhadap peningkatan kekuatan otot tungkai dan power tungkai.

\section{Pembahasan}

Penelitian ini bertujuan untuk pengaruh latihan jump to box, depth jump dan single-leg depth jump terhadap peningkatan kekuatan otot tungkai dan power otot tungkai. Berdasarkan hasil analisa data yang dilakukan terdapat pengaruh yang signifikan antara kelompok I jump to box, kelompok II depth jump dan kelompok III single-leg depth jump terhadap peningkatan kekuatan otot tungkai dan power otot tungkai. Latihan jump to box, depth jump, dan single-leg depth jump merupakan bentuk latihan yang dapat meningkatkan kekuatan otot tungkai dan power otot tungkai. Power merupakan kemampuan otot mengerahkan kekuatan maksimal dalam waktu yang sangat cepat untuk mengatasi beban atau tahanan dengan kecepatan kontraksi yang tinggi. Dalam lompatan, yang berperan adalah kekuatan otot tungkai karena merupakan tumpuan dan menunjang dorongan untuk mengangkat seluruh badan ke atas melayang di udara (Hidayat, Saichudin, \& Kinanti, 2017). Ada beberapa penelitian yang menyatakan hal sama, yaitu penelitian yang dilakukan oleh Mirzaei, Norasteh, Villareal, \& Asadi (2014) depth jump vs countermovement mempunyai pengaruh yang signifikan ketika dilatih dalam 6 minggu. Berikut ini adalah penelitian sejenis yang dilakukan dilakukan oleh Perikles, Mintarto, \& Hasan (2016) yang menyatakan bahwa latihan dari jump to box, front box jump dan depth jump dapat meningkatkan 
Devi Lestya Pembayun, Oce Wiriawan, dan Hari Setijono

Pengaruh Latihan Jump To Box, Depth Jump dan Single Leg Depth Jump Terhadap Peningkatan Kekuatan Otot Tungkai dan Power Otot Tungkai

explosive power otot tungkai dan kecepatan. Hal yang sama juga telah dikemukakakan Baro (2014) yang menyatakan bahwa latihan plyometric (squat jump, split jump (lounges), depth jump, jump up, box jump march, lateral jump (single leg), and lateral jump over the cone (double leg) selama 6 minggu bahwa dapat meningkatkan explosive strength, speed and agility. Latihan jump to box merupakan latihan yang melompat ke atas box dengan ketinggian $40-50 \mathrm{~cm}$.

Berdasarkan hasil analisis dan pembahasan, maka dapat disimpulkan bahwa latihan jump to box, depth jump dan single-leg depth jump memiliki pengaruh terhadap peningkatan kekuatan otot tungkai dan power otot tungkai.

\section{KESIMPULAN DAN SARAN}

Kesimpulan dari penelitian ini adalah terdapat pengaruh yang signifikan dari latihan plyometric khususnya box jump yang terdiri dari tiga bentuk latihan yaitu jump to box, depth jump dan single leg dept jump terhadap peningkatan kekuatan otot tungkai dan power otot tungkai. Berdasarkan hasil kesimpulan yang didapatkan setelah melakukan penelitian, beberapa saran yang akan peneliti sampaikan kepada pembaca yaitu:

1. Penyusunan program latihan harus berdasarkan prinsip individual karena karakter dan kemampuan otot setiap orang berbeda-beda.

2. Jenis latihan jump to box, depth jump dan single leg depth jum disarankan pada program latihan untuk meningkatkan kekuatan otot tungkai dan power otot tungkai

3. Bagi penelitian selanjutnya, dapat dijadikan masukan hasil penelitian apabila memilih permasalahan yang sama sebagai objek penelitiannya dan disarankan untuk menggunakan sampel yang lebih banyak.

\section{DAFTAR PUSTAKA}

Ambarukmi, Dwi H. (2007). Pelatihan Fisik Level I. Jakarta: Asdep Pengembangan Tenaga dan Pembinaan Keolahragaan Deputi Bidang Peningkatan Prestasi dan IPTEK Olahraga Kementerian Negara Pemuda dan Olahraga. 
Ambarwati, D. R., Widiastuti, W., \& Pradityana, K. (2017). Pengaruh Daya Ledak Otot Lengan, Kelentukan Panggul, dan Koordinasi terhadap Keterampilan Tolak Peluru Gaya O'Brien. Jurnal Keolahragaan, 5(2), 207-215. Retrieved from https:/journal.uny.ac.id/index.php/jolahraga/article/view/14918/987 4

Arafat, R. T., Mintarto, E., \& Kusnanik, N. W. (2018). The Exercise Effect Of Front Cone Hops And Zig-Zag Cone Hops Due To Agility And Speed. International Journal of Scientific and Research Publications, 8(2), 250-255.

Baro, M., Sonowal,. (2014). Effect of Selected Plyometric Exercise on Explosive Strength, Speed, and Agility. International Journal of Science and Research, (3)8, 877-878.

Bompa, T.O. \& Buzzichelli, C. (2015). Periodization training for sports (Third Edition). United States of America: Human Kinetic.

Bompa, T.O. \& Haff, G.G. (2009). Periodezation Theory and Methodology of Training. United States of America. Human Kinetics.

Chu, D, A, Myer, G, D. (2013). Plyometrics. United States of America: Human Kinetics.

Hidayat, T., Saichudin, S., \& Kinanti, R. G. (2017). Pengaruh Latihan Plyometric Depth Jump dan Jump To Box Terhadap Power Otot Tungkai pada Pemain Ekstrakurikuler Bolavoli SMK Teknologi Nasional Malang. Jurnal Sport Science, 7(1), 66-73.

Maksum, A. (2012). Metodologi Penelitian Dalam Olahraga. Surabaya: Unipress.

Mirzaei, B., Norasteh, A. A., Villareal, E. S. de, \& Asadi, A. (2014). Effects Of Six Weeks Of Depth Jump Vs. Countermovement Jump Training On Sand On Muscle Soreness And Performance. Kinesiology, 46(1), 97-108.

Muhamad, Yanuar R. (2015). Pengaruh Latihan Front Box Jump Dan Kneeling Squat Jump Terhadap Kekuatan Otot Punggung, Kekuatan Otot Tungkai, dan Power Otot Tungkai (Tesis Magister pendidikan tidak dipublikasikan) Universitas Negeri Surabaya.

Perikles, E. Y., Mintarto, E., \& Hasan, N. (2016). Pengaruh Latihan Jump To Box , Front Box Jump, dan Depth Jump Terhadap Peningkatan Explosive Power Otot Tungkai dan Kecepatan. Media IImu Keolahragaan Indonesia, 6(1), 8-14. Retrieved from https://journal.unnes.ac.id/nju/index.php/miki/article/view/7128 
Devi Lestya Pembayun, Oce Wiriawan, dan Hari Setijono

Pengaruh Latihan Jump To Box, Depth Jump dan Single Leg Depth Jump Terhadap Peningkatan Kekuatan Otot Tungkai dan Power Otot Tungkai

Sukadiyanto \& Muluk, D. 2011. Pengantar Teori dan Metodologi Melatih Fisik. Bandung: Lubuk Agung.

Sukadiyanto, (2011). Pengantar Teori dan Metodologi Melatih Fisik. Bandung : Lubuk Agung. 